Africa who are interested in the geographical study of the districts where they live and work. Many names have already been received through Departments of Geography in Great Britain, and copies of the pamphlet referred to above have been dispatched to them. Anyone who feels able to help the Committee in its work, or who thinks that the Committee may be able to assist him-for example, by recommending the publication of a paper in one of the geographical periodicals - is invited to write to the Secretary, at the School of Geography, Mansfield Road, Oxford, England.

R. W. STEEL

\title{
Nigerian Festival of the Arts
}

THE first Nigerian Festival of the Arts, held in Lagos, was opened by the Governor, Sir John Macpherson, on 23 April and closed with a concert at the Glover Memorial Hall on 27 April 1950.

The function of the Nigerian Festival of the Arts, which it is hoped will be an annual event, has been described by Mr. John Stocker, first Chairman of the Festival Committee. 'In Nigeria', he writes, 'there are a few well-known artists, hundreds of musicians, and thousands of craftsmen and dancers. Their art has been part of the life of the country for generations, they are part of its traditions, but they may die out unless they are encouraged and supported now. To win this encouragement and support, the arts must be given publicity and kept before the public eye.'

Plans for the Festival originated with a meeting of nearly roo interested Europeans and Africans called together by Mr. R. J. Parkhouse, former British Council representative in Nigeria, and Father McCarthy of the Catholic Mission.

The competitive events in the Festival covered many branches of Arts and Crafts. For instance, in the Literature Section, there were awards for original poems in English and in an African language, and for short stories, one-act plays, and essays. Competitive events were held in the different branches of music, drama, and dancing. In the Art Section events included drawing and painting from life and from imagination. There was a large Crafts Section which covered carpentry and joinery, carving, leatherwork, iron and tinplate, beaten brassware, jewellery, textiles, pottery, and other crafts.

Entries for the Festival awards numbered over 600, of which a large proportion were submitted from the more outlying parts of the Territory. Nine silver challenge cups, five of which had been presented by Africans, were awarded for outstanding entries in the various sections, while shields and silver and bronze medals were also awarded.

\section{Théâtre Africain en A.E.F.}

Au Cercle Culturel de Poto-Poto (Moyen-Congo), une section théâtrale est créée, et M. Bandila en a été élu Président. La troupe d'Antoine Ahoudji qui participe à cette activité nouvelle est déjà bien connue. Son Directeur et ses acteurs, presque tous originaires d'A.O.F., font revivre les vieilles légendes de leur pays, ou improvisent sur l'actualité du village, avec un sens de l'observation et un naturel qui les assimilent à des comédiens de métier.

Le Président du Cercle Culturel de Poto-Poto, M. Galingui, a demandé à de très jeunes gens de composer et 'monter' une pièce d'après un conte (souvenir scolaire) pris dans le célèbre 'Mamadou et Binetta'. Par ailleurs, des auteurs se révèlent. Certains sont tentés par les problèmes qu'amène l'évolution; d'autres puisent leurs sujets dans les 'faits divers' du village ou dans les souvenirs d'une enfance en brousse. Ces derniers rédigent des pièces qui laissent une large part à la danse et à la musique, toujours si étroitement mêlées aux événements de la vie africaine. Le Service d'Action Sociale se propose de publier et récompenser les meilleurs ouvrages. Un peintre africain réalise les décors qui nous transporteront où le voudra la fantaisie des auteurs. 